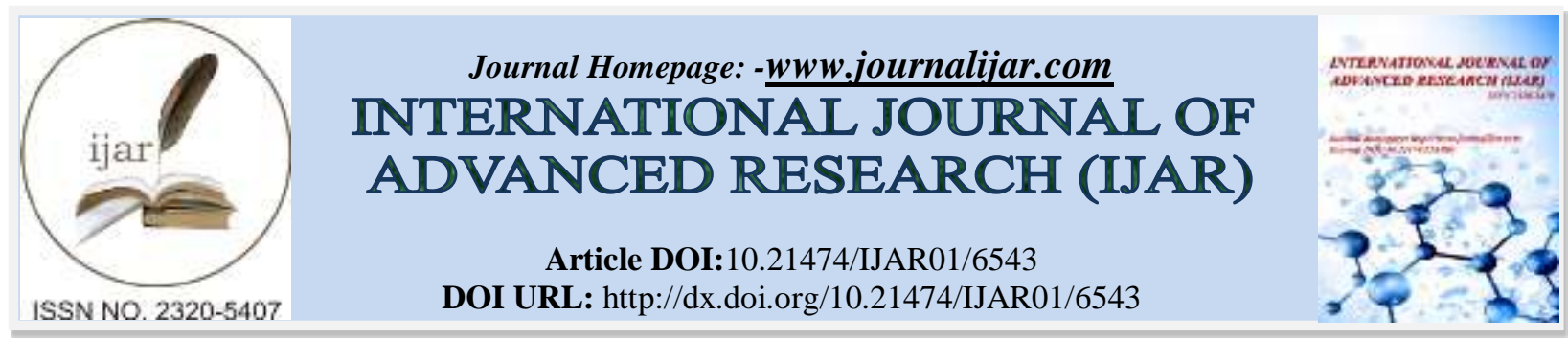

RESEARCH ARTICLE

\title{
THE EFFECT OF APPLICATION OF STRATEGIC COST ANALYSIS METHODS ON MAKING DECISIONS OF PRODUCTION IN SUDANESE INDUSTRIAL FIRMS.
}

\author{
Abdelmotalab osman mahmoud. \\ 1. Assistant Professor of Accounting and Finance. \\ 2. Bayan College for Science and Technology.
}

\section{Manuscript Info}

Manuscript History

Received: 15 December 2017

Final Accepted: 17 January 2018

Published: February 2018

Keywords:-

Strategic, Cost analysis, Value chain, Strategic plan.

\begin{abstract}
This study aimed primarily to explain the effects of implementation of strategic cost analysis methods, on decisions making in the industrial firms. The research used both the analytical descriptive approach and the case study approach. The research community, comprised the employees of both the Sudanese Malaysian Factory and the Egyptian Irion Factory, the number of whom amounts to (360) individuals. The study sample size thus amounts to (44) individuals reached out by using the purposive sampling and to whom the questionnaire form had actually been distributed. The respondents have been (40) individuals, that is to say, (91\%) out of group. The study was found that the strategic cost analysis methods have provided relevant and accurate information to reduce and control the cost and make rational productive decisions. The use of strategic analysis methods has led to increase the competitive ability of the Sudanese industrial firms by enabling them to reduce the cost of products and make additional improvements in the production processes. The use of strategic cost analysis methods has enabled the Sudanese industrial firms to make effective decisions in the process of productive planning and implementation of the strategic plan for production. The research highly recommended the Sudanese firms' management to apply the modern tools of cost management, since the same have a positive effect on the productive decisions and the achievement of competitive advantage.
\end{abstract}

Copy Right, IJAR, 2018,. All rights reserved.

\section{Introduction:-}

The modern international business environment has witnessed numerous consecutive developments in the economic, political and social fields, as a result of the tendency towards freedom of commerce and the use of information technology. This is in addition to the emergence of new industrial systems, which concentrates on complete automation, downsizing of employment and heading towards a market which stemmed as a consequence of gradual transformation of the markets, from a seller's pattern markets to a purchaser pattern market. These drastic changes, have a remarkable effect on firms working in the Sudanese business environment, where the circumstances of modern environment and world economic changes have placed these firms before the inevitability of interaction with the surrounding environment or otherwise, to quit the market. A severe competition, on the other hand, seemed to tighten, whether, on the national, regional or international levels, which resulted in the occurrence of radical changes in the structure of modern manufacturing systems and transformation from the elements of efficiency to the elements of effectiveness by focusing on how to achieve the complete advantage. These firms, however, will not be capable of competition, unless they use modern administrative methods, which are in full conformity with their 
objectives in light of the modern environment, the most significant of which is strategic cost management and creation of value orientation towards the service of consumer and protection of environment.

In view of the increasing orientation towards the utilization of technology and informatics, in particular, which in turn has been reflected in the quantity and quality of such information, needed by the management to make decisions of a production. Based on said facts, numerous firms have tended to adopt the best methods to carry out the different activities, and dispense with traditional systems to treat and follow up costs and use more accurate, new, prompt, flexible and effective methods, which as a matter of fact, has led to increase the attention to costs as one of the most significant factors of the firm's success. This is what provided the same with further strategic dimension in the management and provision of necessary information to serve the process of making strategic decisions of production in industrial firms.

\section{Research Problem:-}

The research problem is to identify the extent to which the application of strategic cost analysis methods affects making decisions of production in industrial firms? In order to answer this research question, the following research questions have been put forward to make effective decisions of production.

1. Do the methods of strategic cost analysis affect the production standards in a manner that makes effective decisions of productions?

2. Is there any effect of the methods of strategic cost analysis on the production strategies that encountering the evolution of production system?

\section{Research objectives:-}

The research aimed to achieve the following objectives:

1. To identify the extent to which the application of strategic cost analysis methods and to benefit from the same in making decisions of production in industrial firms.

2. To clarify the effect of strategic cost analysis methods in the rationalization of

3. Decisions of production in industrial firms.

\section{Research Significance:-}

\section{Scientific Significance:-}

1. The scientific role, the research seeks to introduce is to feed academic libraries in light of the scarcity of studies dealing with the correlation between the strategic cost analysis methods and the decisions of production in industrial firms.

2. To call the organizations and corporations to carry out studies on the methods of strategic cost analysis and how they have been developed.

\section{Practical Significance:-}

1. Evaluation of the application of strategic cost analysis methods in the modern manufacturing environment in the Sudan.

2. Possibility to make benefit from the research findings in the application and development of the methods of strategic cost analysis in industrial firms in order to make a competitive advantage in the long run.

\section{Research Methodology:-}

To achieve the research objectives, the following hypotheses have been tested:

First hypothesis: There is a correlation that is statistically significant between the application of strategic cost analysis methods and the effectiveness of the decisions of production in industrial firms.

Second hypothesis: There is a correlation that is statistically significant between the application of strategic cost analysis methods and the implementation of strategies of production in industrial firms.

\section{Research Methodology:-}

The research used the analytical, descriptive approach, which is most convenient with the research objectives and its procedures. This approach is based on the study of the phenomenon as it is in reality and contributes significantly to accurately describe the same, in a way that clarifies its characteristics by the collection and analysis and interpretation of the data. 


\section{Literature Review:-}

The Study of (Mahmoud 2010): The study aimed to clarify the role in which the method of strategic analysis affects the support of the competitive position of firms. The research hypothesized that value chain does not represent the main performance in the management and analysis of strategic cost. The perspective of costs management after having a comprehension of the contents relating to how the firm has chosen a policy of competition is an insignificant matter for cost analysis. The use of cost drivers does not lead to increase the competitive ability of industrial firm. The research has reached, the fact that the system of strategic cost analysis is characterized as having the ability to expand the scope of accounting information to include non-financial information such as factors of success, which help in supporting the competitive position to make decisions. The research, on the other hand, has recommended having more attention to qualify and provide training for cost accountants in the Syrian industrial firms, in order to gain knowledge in modern systems and methods of cost accounting and management accounting as well as the continuous development of the same.

The Study of (Hutaibat, 2011): This study aimed to introduce the value chain to the higher education, and to identify the extent to which the value chain contributes to create the competitive advantage for higher education based on resources and potentialities- a case study applied to the Ministry of Education in Jordan. The study has been applied to the Ministry of Education in Jordon. The study used the analytical, descriptive approach, where, the same reached a number of findings, the most significant of which are the following: The method of the value chain for strategic management accounting contributes substantially to create competitive advantage for higher education, pursuant to available resources. The value chain analysis deemed an effective tool for the strategic management and strategic cost analysis where, appropriate information is available. The study recommended applying the value chain method in the different firms in the future.

The Study of (El Hwaity, 2013): This study aimed to highlight the significance of the integration of tools and methods of strategic cost management to maximize the firm's value and support the competitive advantage. The study as well, aimed to clarify the possibility of the application of strategic cost management in industrial firms operating in the Gaza Strip. To effect the field study, the research used the analytical descriptive approach. Based on this account, the study has reached a number of findings, including the following: Lack of effective costing system in industrial firms. The study also ensured the significance of application of strategic management approach, since the same achieves much more advantages, despite, some difficulties encountering the application of this approach. The study has also reached, the fact that firms apply the tools and methods of this approach in simplified a manner, without being adhered to such scientific and systematic specified procedures.

The Study of (Saba, 2014): This study aimed to identify the extent to which firms of Palestinian services sector working in the Gaza Strip use the strategic cost management approach and its decision making role. To achieve this objective, the study used the analytical descriptive approach. The study also sought to test the following hypotheses: Firms of Palestinian services sector working in the Gaza Strip use a cost accounting system applied pursuant to the scientific basis of accounting, which meets the need of managements to make decisions. Firms of Palestinian services sector working in the Gaza Strip use the tools and methods of strategic cost management approach. The study has reached, the fact that the cost system applied in the Palestinian services sector firms working in the Gaza Strip depends largely on scientific accounting basis, which meets the need of managements to make decisions.

The Study of (Abu-Anya, 2015): This study aimed primarily to determine the most important methods of strategic cost analysis and the extent to which the same is applied in the Sudan. The study tested a number of hypotheses, the most significant of which are the following: There is a correlation that is statistically significant between the application of value chain analysis methods and the reduction of costs in industrial firms. There is a correlation that is statistically significant between the application of the target cost method and the reduction of costs in industrial firms. There is a correlation that is statistically significant between the application of cost drivers' method and the reduction of costs in the Sudanese industrial firms. This study has reached a number of findings, including the Following: The method of value analysis reduces the costs by the treatment of traditional methods of cost reduction in the Sudanese industrial firms.

Indeed, said prior literature in general tends to address the role of strategic analysis approach in supporting the competitive position of firms, and to identify the extent to which the value chain contributes significantly to create competitive advantage for higher education based on resources and potentialities. This is in addition to investigate the utilization of the Palestinian services sector firms working in the Gaza Strip on strategic cost management 
approach and its role in the decision making. In comparison, the current research in question is distinct as having been the ever first research study to investigate the application of strategic cost analysis methods in foreign steel factories in the Sudan, to the best of researchers' knowledge. The research, on the other hand, sought to clarify the correlation between the application of strategic cost analysis methods and the making of decisions of production in industrial firms.

\section{Conceptual Framework:- Strategic cost analysis:-}

Strategic cost analysis, and Strategic cost management are synonymous concepts for the collection and analysis of financial and non-financial information derived from both internal and external business environment of the firm, with a view to reaching the best of strategies which help in achieving the firm's competitive advantages in both long and short terms, (Abdu Elaziz, 2013). However, some writers are in the opinion that strategic cost analysis, represents a mix of three types of analysis, that is to say, value chain analysis, cost drivers analysis and competitive position analysis, (Foda, 2009). Strategic cost analysis reflects the managerial utilization of cost information in a manner that is closely related to one or more of the four following strategic cost management stages, (Smith, 2010).

1. To set out such strategies as to effect overall tracks of value and work cell using effective strategic methods.

2. To develop and implement any relevant techniques to implement strategies.

3. To develop and implement control methods to tightening the steps of success of implementation, and hence to have a success in the achievement of strategic objectives.

4. To determine the methods of follow up the implementation of strategies and control over performance in order to ensure the success of the strategy in achieving its objectives.

\section{Strategic orientation:-}

Strategic orientation comprises of three prominent orientations, that's to say, orientation towards the client, orientation towards competitor and orientation towards liquidity or product, (Abu Zunt, 2011). Strategic orientation has also been defined as a relatively constant concept in nature and reflects a general overview of its environment. Strategic orientation, on the other hand, deemed to be a method to draw the timetable of the decisions, which directed to adapt the firm. Strategic orientation also forms internal policies and procedures set to achieve the objectives, (Ingrid, 2015). Some researchers have also defined the information system set up to serve the strategic objectives, as a system which provides the senior management with the information needed by the same at the different stages of the strategic planning, (Amani, 2006).

\section{Strategic cost analysis tools:-}

Strategic cost analysis tools are a mix of three types of analysis as per the following:

\section{Analysis of competitive strategies:-}

Competitive strategies are a group of actions designed to achieve competitive advantages in products environment or in specific markets for specific objectives, in this regard, the firm might follow more than one competitive strategy at the same time. In the same context, there are three main competitive strategies from which the selection can be made based on the competition circumstances and the firm's abilities, (Ibrahim, 2012) as follows.

Focus strategy: This strategy aims to focus on a specific line of production or specific client, or specific market or sector.

1. Differentiation strategy: This includes a number of activities performed by the firm in order to add an advantage of its products to be distinct from other products, whether in terms of price or quality or technology.

2. Cost Leadership Strategy: This strategy depends on the ability of the firm to render its services and products at the lowest cost, compared to other competitors without prejudice as to the quality of the products or the factors affecting the cost behavior, (Eid, 2014).

\section{Value chain analysis:-}

Value chain analysis deemed as one of the most significant tools of strategic cost management, which is a group of consecutive functions that add real value to the products or services, starting from raw materials and up to the final usage of the product or service rendered for the client (Eid, 2014). The value chain is also used as a tool to test the extent of the contribution of the firm's activities in the achievement of competitive advantages. The same is, however, deemed as subsequent procedure to measure both of the ability of the elements of the value and the elements of the addition to the value. Where, the results of the measurement may reveal the aspects of differentiation or deficiency in the realization of strategic cost ability at the level of elements' value.

According to (Mostafa and Huron, 2011), the value chain divided into the following: 
- Primary activities: These are the activities which have a direct relation to the production and distribution of commodities and services in the firm. They also work to generate a value and price for the consumer or client, since they might contribute significantly to effect a direct transformation of the firm's operations.

- Secondary activities: These are the activities, which support the primary activities, and render the process of production and distribution more possible, that is to say, they work to support the internal infrastructure and effect the work of primary activities.

\section{Cost driver analysis:-}

Cost driver is defined as "a factor that allows the interpretation of change in cost, therefor, a correlation should be established between the cost driver and cost activity. Cost driver, thus effect critically the reduction of cost activity of the final products (Algina, 2013). Cost driver often being divided into four levels as per the following: Cost driver at the level of firm's structure, the control over which can be achieved through the study of the extent to which the same is in conformity with the strategy of the firm as well as with its vision, mission and objective of its establishment. This is however, would be realized by the determination of the operations and activities required to achieve the objectives and strategies of the firm coupled with a continuous review to know the extent of the realization of these objectives. As to cost drivers at the level of the means and methods of implementation, the control over which can be achieved through the critical thinking and continuous evaluation of the efficiency of the means and methods of production as well as the design of manufacturing processes or product design. The structural drivers, on the others, are relating to the strategic decisions of the firm as well as to the scope, range, previous experience, technical level and the degree of complication in its operations. Regarding the operational cost drivers, they are closely related to the ability of the firm in making successful implementation of the requirement of its clients, which are represented in six elements, namely, the extent of the commitment of human element to development, total quality management, extent of utilization of capacity, efficiency of manufacturing, extent of product effectiveness design and its ingredients and the extent of organized benefit from overlap relation with exporters and client. Cost drivers' analysis, thus, provides financial and non-financial data and information, the financial information of which reflects the correlation between the cost activity and its outputs, for instance, the cost of defected production and the cost of the level of quality, (Ibrahim, 2013)

\section{Strategic Planning for Production Process:-}

Production system, in these days, is passing through great developments, which viewed the same, form a dynamic perspective as to allow the adoption with changes in both the environment and the market. The new position of the firm has facilitated the performance of many research studies within the field of production. This is may be effected by the analysis of the primary data and set up of strategic plans with respect to manufacturing processes to describe the evolution of the production systems in the medium and run and long run to establish the structure of the firm by clarifying the steps of the strategic plan of the production and to identify the effects of strategic management on the function of production and to illustrate the strategic role of the function of production as well as other strategies related to the different objectives of the production, (Zahrawi, 2009).

Strategic cost analysis and administrative decisions making:

Strategic cost analysis is used to make administrative decisions through the adherence to five stages in order to select a specific available alternative in the process of making decisions production, as per the following, (Nur and Gumoa, 2014).

1. First Stage: to determine strategic issues related to the decision, which in turn help the decision-maker to determine a comprehensive list of strategic alternatives.

2. Second Stage: to determine the criterion by which the decision can be made, in this regard, the process of the short run objectives' setting will be one of the easiest decisions that encountering the managers, which is on contrary when making long run strategic decisions.

3. Third Stage: is to analyze relevant information, in this stage, the relevant cost and strategic costs will be analyzed.

4. Fourth Stage: is to choose and implement the best alternative, such a selection is often made based on the analysis of both relevant cost and strategic costs.

5. Fifth Stage: is to evaluate the performance of implemented decision, using the feedback to determine the correlation between the current decision and the future decisions.

\section{Research Methodology:-}

Research community and research sample:-

The research community is comprised of employees working in the Malaysian Sudanese Steel Factory and the Egyptian Steel Factory, the number of whom is (360) individuals, taking into the account, the fact that the two 
factories are working in the iron and steel. To effect the field study, a purposive sample of the said research community number has been selected, the number of which is (44) respondents from among those who are working in the senior management and financial and production units. However, the motive behind the selection of this category is based upon the fact that the position of these employees dictates to them to bear the responsibility of the management of production costs and help in providing such information as to support the competitive position of their firms. A questionnaire form has been distributed to the sample of the research community and the respondents are (40) individuals who answered overall questionnaire statements and questions, that is to say, (91\%) of the research community sample.

\section{Research Tool:-}

The research used the questionnaire as a primary tool to collect data, where, the same was designed to effectively diagnose and measure the main variables of the research, the determination of which is based mainly on previous studies, in addition to the viewpoints of some scholarly persons within the research related academic discipline, whose substantial observations have been considered and some amendments have been made accordingly to the research study, which comprised three parts.

A letter enclosed with the questionnaire form has been sent to the respondents, in which he was better informed about the research subject and objective as well as the purpose of designing the questionnaire, which includes two

\section{Main Sections:-}

First Section: is related to personal information of the research sample individuals.

Second Section: this section contains (14) statements, for which the research sample individuals were required to determine their responses to what has been described by each statement in accordance with gradual Likert quinary Scale, which comprises five levels (strongly agree, agree, undecided, disagree, and strongly disagree. The questionnaire also contains (7) statements for each hypothesis.

\section{Measuring Tool Validity:-}

The research has tested and proved the validity of the measurement tool following numerous stages and steps, stating by the process of verifying the tool validity, namely to ensure that it is valid to measure what has been laid down to be measured, depending on the virtual validity. To prove the validity of the tool the same has been referred to learned referees with remarkable expertise and specialization, where, they provided with more information about the research objectives and hypotheses, in order to take cognizance. Based on the viewpoints and suggestions of those scholars the questionnaire has taken its final form which distributed to the research sample.

\section{Internal Stability:-}

Alpha de Cronbach coefficient has been used to measure the validity of the tool's stability, which is statistically significant when these value are equal or greater than (0.6), (Guda,2008). The value of Alpha de Cronbach was found equal to 0.627 whereas, it is greater than $60 \%$ therefore, it is statistically significant.

Table (1): statistical stability and validity of responses of individuals of survey sample

\begin{tabular}{|l|l|}
\hline Paragraphs & Cronbach Alpha de \\
\hline First hypothesis & 0.600 \\
\hline Second hypothesis & 1.498 \\
\hline $\begin{array}{l}\text { Questionnaire in Complete } \\
\text { Form }\end{array}$ & 0.705 \\
\hline
\end{tabular}

Source: prepared by Researcher as cited from the field study, 2016.

\section{Research Limits:-}

- $\quad$ Research spatial limits: is the Malaysian Sudanese Steel Factory and the Egyptian Steel Factory.

- $\quad$ Research temporal limits: is the year, 2016.

Analysis and discussion of research findings:Firstly: Description of sample characteristics:

Table 2:- Characteristics of research sample

\begin{tabular}{|l|l|l|l|}
\hline Variable & Categories & Frequencies & Percentage \\
\hline \multirow{5}{*}{ Age } & Less than 30 years. & 9 & $23 \%$ \\
\cline { 2 - 4 } & $30-40$ Years & 13 & $33 \%$ \\
\cline { 2 - 4 } & $41-50$ Years & 15 & $38 \%$ \\
\cline { 2 - 4 } & More than 50 years & 3 & $6 \%$ \\
\hline Scientific Qualification & Postgraduate Studies & 5 & $12.5 \%$ \\
\hline
\end{tabular}




\begin{tabular}{|l|l|l|l|}
\hline & Bachelor & 30 & $75 \%$ \\
\cline { 2 - 4 } & Diploma & 5 & $12.5 \%$ \\
\hline \multirow{5}{*}{ Scientific specialization } & Accounting & 20 & $50 \%$ \\
\cline { 2 - 4 } & Costing & 12 & $30 \%$ \\
\cline { 2 - 4 } & Business Administration & 6 & $15 \%$ \\
\cline { 2 - 4 } & Others & 2 & $5 \%$ \\
\hline \multirow{5}{*}{ Years of Experience } & Less than 5 years & 10 & $25 \%$ \\
\cline { 2 - 4 } & $5-10$ Years & 14 & $35 \%$ \\
\cline { 2 - 4 } & $11-15$ years. & 6 & $15 \%$ \\
\cline { 2 - 4 } & 16 and more & 10 & $25 \%$ \\
\hline
\end{tabular}

Table No. (2) refers to the fact that research sample individuals whose ages are between 30 years and less than 40 years, represents $33 \%$ and those who their ages are between 40 years and less than 50 years represent $38 \%$ of the sample. It is remarkable that $75 \%$ of the research sample obtaining Bachelor degree and the highest frequency rate has come from the accountants' category which reached $50 \%$. This indicates the ability of the respondents to understand the questionnaire statements. The level of the experience of the research sample is remarkably high.

\section{Responses of research sample individuals to first hypothesis statement:-}

First research hypothesis, provides for the following: there is a correlation that is statistically significant between the application of the methods of strategic cost analysis and the effectiveness of the decisions of production in industrial firms. In order to verify such a correlation, frequencies and percentages were used to know both positive and negative responses, as shown below by table No 3.

Table No 3:- frequency distribution of research sample individuals' responses to first hypothesis statements:

\begin{tabular}{|c|c|c|c|c|c|c|}
\hline \multirow[t]{2}{*}{ M } & \multirow[t]{2}{*}{ Statement } & \multicolumn{5}{|c|}{ level of agreement, Frequency and percentage $\%$} \\
\hline & & $\begin{array}{l}\text { Strongly } \\
\text { Agree }\end{array}$ & Agree & Disagree & Undecided & $\begin{array}{c}\text { Strongly } \\
\text { Disagree }\end{array}$ \\
\hline 1 & $\begin{array}{l}\text { Strategic cost analysis methods } \\
\text { help in decision - making of the } \\
\text { movements of production costs. }\end{array}$ & $\begin{array}{l}14 \\
70 \%\end{array}$ & $\begin{array}{l}6 \\
30 \%\end{array}$ & - & - & - \\
\hline 2 & $\begin{array}{l}\text { Strategic cost analysis methods } \\
\text { enable cost reduction and control } \\
\text { during the stages of production. }\end{array}$ & $\begin{array}{l}13 \\
65 \%\end{array}$ & $\begin{array}{l}7 \\
35 \%\end{array}$ & - & - & - \\
\hline 3 & $\begin{array}{l}\text { Strategic cost analysis methods } \\
\text { help the management to use } \\
\text { information costs to make decision } \\
\text { of production. }\end{array}$ & $\begin{array}{l}26 \\
65 \%\end{array}$ & $\begin{array}{l}8 \\
20 \%\end{array}$ & $\begin{array}{l}6 \\
15 \%\end{array}$ & - & - \\
\hline 4 & $\begin{array}{l}\text { Strategic } \\
\text { methods contribute to effect the } \\
\text { comparison between the } \\
\text { performance of firms applying } \\
\text { these methods and the performance } \\
\text { of the competitors in the market. }\end{array}$ & $\begin{array}{l}12 \\
30 \%\end{array}$ & $\begin{array}{l}20 \\
50 \%\end{array}$ & $\begin{array}{l}8 \\
20 \%\end{array}$ & - & - \\
\hline 5 & $\begin{array}{l}\text { Value chain supports the decisions } \\
\text { of production through primary and } \\
\text { secondary activities. }\end{array}$ & $\begin{array}{l}28 \\
70 \%\end{array}$ & $\begin{array}{l}8 \\
20 \%\end{array}$ & $\begin{array}{l}4 \\
10 \%\end{array}$ & - & - \\
\hline 6 & $\begin{array}{l}\text { Industrial firms adopt the methods } \\
\text { of strategic analysis in making } \\
\text { decisions of production which } \\
\text { increases their competitiveness. }\end{array}$ & $\begin{array}{l}26 \\
65 \%\end{array}$ & $\begin{array}{l}8 \\
20 \%\end{array}$ & $\begin{array}{l}6 \\
15 \%\end{array}$ & - & - \\
\hline 7 & $\begin{array}{l}\text { Strategic cost analysis methods } \\
\text { lead to reduce the cost of downtime } \\
\text { as a result of technical reasons of } \\
\text { production. }\end{array}$ & $\begin{array}{l}26 \\
65 \%\end{array}$ & $\begin{array}{l}14 \\
35 \%\end{array}$ & - & - & - \\
\hline
\end{tabular}

As shown in table No (3) it is clear that the responses of the respondents have been concentrated on the two alternatives, strongly agree, and agree, which indicates their trends towards the correlation between the application of the methods of strategic cost analysis and the production decisions. 
Secondly: Responses of research sample individuals to second hypothesis statement:

Second research hypothesis, provides for the following: there is a correlation that is statistically significant between the application of the methods of strategic cost analysis and the implementation of production strategy in industrial firms. In order to verify such a correlation, frequencies and percentages were used to know both positive and negative responses, as shown below by table No 4 .

Table No 4:- frequency distribution of research sample individuals' responses to second hypothesis statements:

\begin{tabular}{|c|c|c|c|c|c|c|}
\hline \multirow[t]{2}{*}{$\mathbf{M}$} & \multirow[t]{2}{*}{ Statement } & \multicolumn{5}{|c|}{ level of agreement, Frequency and percentage \% } \\
\hline & & $\begin{array}{l}\text { Strongly } \\
\text { Agree }\end{array}$ & Agree & Undecided & Disagree & $\begin{array}{l}\text { Strongly } \\
\text { Disagree }\end{array}$ \\
\hline 1 & $\begin{array}{l}\text { Strategic cost analysis } \\
\text { methods support the } \\
\text { strategy of } \\
\text { management of } \\
\text { Production in } \\
\text { industrial enterprises. }\end{array}$ & $\begin{array}{l}16 \\
40 \%\end{array}$ & $\begin{array}{l}12 \\
30 \%\end{array}$ & $\begin{array}{l}12 \\
30 \%\end{array}$ & - & - \\
\hline 2 & $\begin{array}{l}\text { Strategic cost analysis } \\
\text { methods help in } \\
\text { implementing of cost- } \\
\text { effectiveness in the } \\
\text { implementation of the } \\
\text { strategic plan of } \\
\text { production associated } \\
\text { with the process of } \\
\text { decision-making in } \\
\text { industrial firms. }\end{array}$ & $\begin{array}{l}28 \\
70 \%\end{array}$ & $\begin{array}{l}4 \\
10 \%\end{array}$ & $\begin{array}{l}6 \\
15 \%\end{array}$ & $\begin{array}{l}2 \\
5 \%\end{array}$ & - \\
\hline 3 & $\begin{array}{l}\text { Strategic management } \\
\text { of production is linked } \\
\text { to the decisions of } \\
\text { production in industrial } \\
\text { firms. }\end{array}$ & $\begin{array}{l}26 \\
65 \%\end{array}$ & $\begin{array}{l}8 \\
20 \%\end{array}$ & $\begin{array}{l}6 \\
15 \%\end{array}$ & - & - \\
\hline 4 & $\begin{array}{l}\text { Strategic cost analysis } \\
\text { methods contribute } \\
\text { significantly to } \\
\text { continuous lifting of } \\
\text { a number of products } \\
\text { in terms of quality in } \\
\text { industrial firms. }\end{array}$ & $\begin{array}{l}12 \\
30 \%\end{array}$ & $\begin{array}{l}20 \\
50 \%\end{array}$ & $\begin{array}{l}8 \\
20 \%\end{array}$ & - & - \\
\hline 5 & $\begin{array}{l}\text { Strategic cost analysis } \\
\text { methods work to } \\
\text { reduce the life of } \\
\text { products, especially } \\
\text { production lead time } \\
\text { and delivery. }\end{array}$ & $\begin{array}{l}2 \\
5 \%\end{array}$ & $\begin{array}{l}26 \\
65 \%\end{array}$ & $\begin{array}{l}10 \\
25 \%\end{array}$ & - & 2 \\
\hline 6 & $\begin{array}{l}\text { Strategic cost analysis } \\
\text { methods support the } \\
\text { standards of production } \\
\text { performance and } \\
\text { competitive pressure } \\
\text { in industrial firms. }\end{array}$ & $\begin{array}{l}26 \\
65 \%\end{array}$ & $\begin{array}{l}8 \\
20 \%\end{array}$ & $\begin{array}{l}6 \\
15 \%\end{array}$ & - & - \\
\hline 7 & $\begin{array}{l}\text { Strategic cost analysis } \\
\text { methods enable } \\
\text { achieving effective } \\
\text { decisions in the process } \\
\text { of production planning } \\
\text { in industrial firms. }\end{array}$ & $\begin{array}{l}26 \\
65 \%\end{array}$ & $\begin{array}{l}14 \\
35 \%\end{array}$ & - & - & - \\
\hline
\end{tabular}

As shown in table No (4) it is clear that the responses of the respondents have been concentrated on the two alternatives, strongly agree, and agree, which indicates their trends towards the correlation between the application of the methods of strategic cost analysis and the implementation of production strategy. 


\section{Test of first hypothesis findings:-}

First research hypothesis, provides for the following: there is a correlation that is statistically significant between the application of the methods of strategic cost analysis and the effectiveness of decisions of production in industrial firms.

This hypothesis aimed to clarify the fact that there is a correlation that is statistically significant between the application of the methods of strategic cost analysis and the effectiveness of decisions of production in industrial firms. In order to verify the validity of this hypothesis, the research sample has been inquired to know their viewpoints on a number of variable demonstrated in table No (5). This is by responding to the statements of this hypothesis. To effect testing the research hypotheses, the weighted arithmetic means (response force) and standards deviations of the research sample individuals' responses were calculated based on each hypothesis statements. The findings of this hypothesis testing were demonstrated in table (5).

\section{Table (5) Test of first hypothesis findings:-}

Based on what has been shown in table (5), the following analysis would be considered:

1. Arithmetic means of the research sample individuals' responses to first hypothesis statements is ranging from (4.70 to 3.55) which are more closely to weight (5). That means, most of the individuals of research sample are strongly supporting the validity of the hypothesis, the reason is that the individuals of the research sample have noticed that there is a correlation that is statistically significant between the application of strategic cost analysis methods and the production decisions in industrial firms. The values of the standard deviation of the responses to the hypothesis statements have also been ranged from (0.99 to 0.47$)$. This is however, indicates the great consistency in the responses of the research sample individuals to these statements, that is to say, they have been agreed to large extent to these statements.

2. Findings shown in table (1) indicate that overall research sample individuals are agreed to accept the hypothesis, and if there were some differences of statistical significance in the responses of the research sample individuals, this can be determined by using chi-square to effect significant differences between each hypothesis statements responses.

3. The referred to above table, indicates that the probable value of chi-square for the significant differences of the different responses of the respondents to the first hypothesis statements is ranging from (0.24 to 0.00) and most of these values are less than the significant difference of $(0.05)$, which indicates that there are insignificant differences between the responses to the statements of the hypothesis.

Based that account, it is obvious that most of the research sample individuals, with different specializations, are in the opinion that there is a correlation that is statistically significant between the application of strategic cost analysis methods and the decisions of production in industrial firms. This is what proves the validity of the hypothesis. This is, however, indicates that industrial firms in research question are characterized as using modern methods of strategic analysis, which contributes significantly to have information that help in making production deacons. This finding is consistent with the study of (Elbishtawi, Garira,2015).

\section{Test of second hypothesis findings:-}

The second research hypothesis provided that: There is a correlation that is statistically significant between the application of strategic cost analysis methods and the implementation of production strategy in industrial firms.

This hypothesis aimed primarily to clarify that there is a correlation that is statistically significant between the application of strategic cost analysis methods and the implementation of production strategies in industrial firms. In order to verify the validity of this hypothesis, the research sample individuals have been inquired to know their viewpoints on a number of variables demonstrated in table No (6), regarding the responses to this hypothesis. To effect testing this research hypothesis, the weighted arithmetic means (response force) and standards deviations of the research sample individuals' responses were calculated based on each hypothesis statements. The findings of this hypothesis testing were demonstrated in table (6).

Table No, 6:- Test of second hypothesis findings:

\begin{tabular}{|c|c|c|c|c|c|c|c|c|c|}
\hline \multirow{2}{*}{$\begin{array}{l}\mathrm{M} \\
\mathrm{M}\end{array}$} & \multirow[t]{2}{*}{ Statement } & \multirow[t]{2}{*}{$\begin{array}{l}\text { Arithmet } \\
\text { ic mean }\end{array}$} & \multirow{2}{*}{$\begin{array}{l}\text { Standar } \\
\mathrm{d} \\
\text { Deviatio } \\
\mathrm{n}\end{array}$} & \multicolumn{2}{|c|}{$\begin{array}{l}\text { measurement } \\
\text { of statement }\end{array}$} & \multirow{2}{*}{$\begin{array}{l}\text { Valu } \\
\text { e of } \\
\text { chi- } \\
\text { squar } \\
\text { e }\end{array}$} & \multirow{2}{*}{$\begin{array}{l}\text { Degree } \\
\text { of } \\
\text { freedo } \\
\mathrm{m}\end{array}$} & \multirow{2}{*}{$\begin{array}{l}\text { Probabl } \\
\text { e chi- } \\
\text { square } \\
\text { value }\end{array}$} & \multirow[t]{2}{*}{$\begin{array}{l}\text { Interpretatio } \\
\mathrm{n}\end{array}$} \\
\hline & & & & $\begin{array}{l}\text { Weig } \\
\text { ht }\end{array}$ & $\mathrm{e}^{\text {Degre }}$ & & & & \\
\hline 1 & $\begin{array}{l}\text { Strategic cost } \\
\text { analysis } \\
\text { methods }\end{array}$ & 4.10 & 0.85 & 4 & Ok & 0.733 & 2 & 0.82 & $\begin{array}{l}\text { Statistically } \\
\text { insignifican } \\
t\end{array}$ \\
\hline
\end{tabular}




\begin{tabular}{|c|c|c|c|c|c|c|c|c|c|}
\hline & $\begin{array}{l}\text { support the } \\
\text { strategy of } \\
\text { management } \\
\text { of production } \\
\text { in industrial } \\
\text { firms. }\end{array}$ & & & & & & & & \\
\hline 2 & $\begin{array}{l}\text { Strategic cost } \\
\text { analysis } \\
\text { methods help } \\
\text { in the } \\
\text { implementati } \\
\text { on of } \\
\text { strategic plan } \\
\text { of production } \\
\text { associated } \\
\text { with the } \\
\text { process of } \\
\text { decision- } \\
\text { making in } \\
\text { industrial } \\
\text {.firms }\end{array}$ & 4.45 & 0.95 & 5 & Ok & $\begin{array}{l}2200 \\
0\end{array}$ & 3 & 0.00 & $\begin{array}{l}\text { Statistically } \\
\text { significant }\end{array}$ \\
\hline 3 & $\begin{array}{l}\text { Strategic } \\
\text { management } \\
\text { of Production } \\
\text { is linked to } \\
\text { the strategic } \\
\text { management } \\
\text { decisions of } \\
\text { production in } \\
\text { industrial } \\
\text { firms. }\end{array}$ & 4.05 & 0.95 & 4 & Ok & 5200 & 3 & 0.00 & $\begin{array}{l}\text { Statistically } \\
\text { significant }\end{array}$ \\
\hline 4 & $\begin{array}{l}\text { Strategic cost } \\
\text { analysis } \\
\text { methods } \\
\text { contribute } \\
\text { significantly } \\
\text { to continuous } \\
\text { lifting of } \\
\text { a number of } \\
\text { products in } \\
\text { terms of } \\
\text { quality in } \\
\text { industrial } \\
\text { firms. }\end{array}$ & 3.85 & 1.35 & 4 & Ok & $\begin{array}{l}1100 \\
0\end{array}$ & 4 & 0.00 & $\begin{array}{l}\text { Statistically } \\
\text { significant }\end{array}$ \\
\hline 5 & $\begin{array}{l}\text { Strategic cost } \\
\text { analysis } \\
\text { methods } \\
\text { work to } \\
\text { reduce the } \\
\text { life } \\
\text { products, of } \\
\text { especially } \\
\text { production } \\
\text { lead time and } \\
\text { delivery. }\end{array}$ & 3.65 & 1.27 & 4 & Ok & $\begin{array}{l}6500 \\
0\end{array}$ & 3 & 0.01 & $\begin{array}{l}\text { D. } \\
\text { statistically }\end{array}$ \\
\hline 6 & $\begin{array}{l}\text { Strategic cost } \\
\text { analysis } \\
\text { methods } \\
\text { support the } \\
\text { standards of } \\
\text { production } \\
\text { performance } \\
\text { and } \\
\text { competitive } \\
\text { pressure } \\
\text { in industrial } \\
\text { firms }\end{array}$ & 3.85 & 1.21 & 4 & Ok & 3600 & 4 & 0.16 & $\begin{array}{l}\text { Statistically } \\
\text { insignifican } \\
\text { ce }\end{array}$ \\
\hline 7 & Strategic cost & 4.45 & 0.51 & 4 & Ok & 0.271 & 4 & 0.66 & Statistically \\
\hline
\end{tabular}




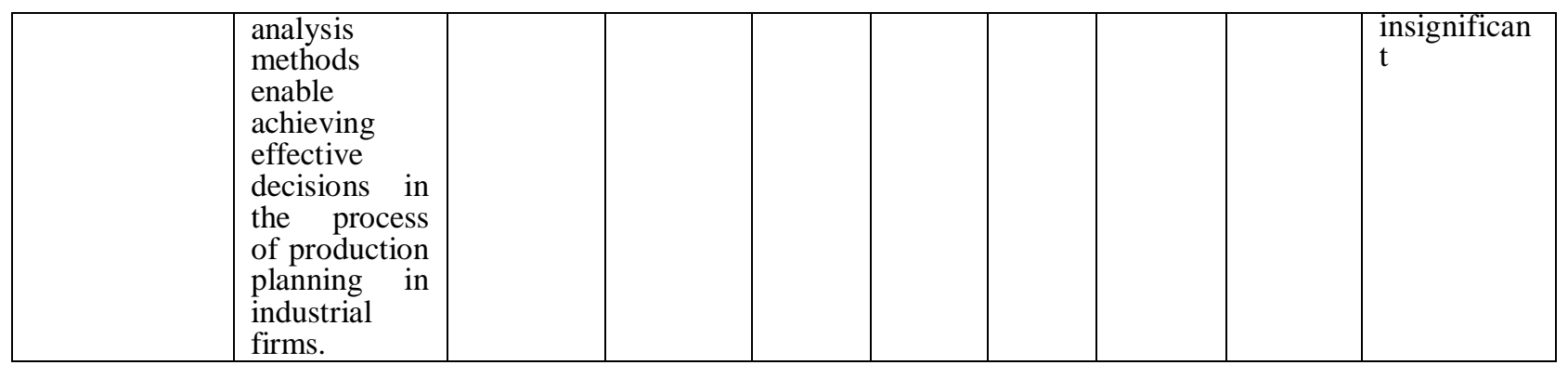

In view of table No, (6) the following analysis would be considered:

1. Arithmetic means of the research sample individuals' responses to second hypothesis statements is ranging from (4.45 to 3.65) which are more closely to weight (4). That means, most of the individuals of research sample were agreed that there is a correlation that is statistically significant between the application of strategic cost analysis methods and the implementation of production strategy in industrial firms.

2. The values of the standard deviation of the responses to this hypothesis statements have been ranged from (1.35 to 0.51 ). This is however, indicates the great consistency in the responses of the research sample individuals to these statements, that is to say, they have been agreed to large extent to these statements.

3. Findings shown in table (2) indicate that there are some differences of statistical significance in the responses of the research sample individuals based on the employment of chi-square test to identify any significant differences between each hypothesis statements responses.

4. The referred to above table, indicates that the probable value of chi-square for the significant differences of the different responses of the respondents to the second hypothesis statements is $(0.00)$ and most of these values are less than the significant difference of $(0.05)$, which indicates that there are insignificant differences between the responses to the statements of the hypothesis.

In view of what has been said, it is obvious that most of the research sample individuals, with different specializations, are in the opinion that there is a correlation that is statistically significant between the application of strategic cost analysis methods and the implementation of the production strategy in industrial firms. This is, however, indicates that the cost system currently in force in industrial firms in research question supports the implementation of the production strategy by linking the long term strategic objectives with the short term objectives. This finding is consistent with the study of (Ibn Said, Ahamed,2013).

\section{Research Findings and Recommendations:-}

Research Findings:-

1. Strategic cost analysis methods provided such correct and accurate information as to reduce and control cost and take production decisions.

2. Application of strategic cost analysis methods has led to increase the competitive ability of the Sudanese industrial firms, by reducing the cost of products and making additional improvements to the production processes.

3. Application of value chain method deemed as a real addition to the value of the production process, through its primary and secondary activities relating the production processes.

4. Adoption of the Sudanese industrial firms of the methods of strategic cost analysis, has contributed significantly to the continuous lifting of some of their products in terms of quality, among other firms.

5. Methods of strategic cost analysis have enabled the Sudanese industrial firms to make effective decisions in the process of production planning and the implementation of the strategic plan of production.

\section{Research Recommendations:-}

Based on said research findings, the research concluded with a set of recommendations including the following:

1. The research recommended Sudanese firms managements to apply the modern methods of cost management since the same has a positive effect on the production decisions and the achievement of additional competitive advantage.

2. The research recommended the establishment of cost section in the Sudanese industrial firms in quisition, concerned with the application of the methods of strategic cost analysis.

3. The research recommended having interest in qualifying the accountants in the field of cost and management accounting and undertake a training plan with a view to building their capacities in the field strategic cost management. 


\section{References:-}

1. Ibrahim Khalid Adly Ahmed. (2013). The role of strategic cost analysis in increasing the competitive advantage of firms under modern manufacturing environment, unpublished Master degree in accounting Khartoum: Alneelain University, 2013, p.70.

2. Ibrahim Mahmoud Ahmad. (2010) strategic cost analysis under modern manufacturing environment and support of competitive advantage. Magazine of development of Mesopotamia, Iraq: Mosul University, Vol. 32, No. 101, p. 98.

3. Al bshtawi, Suleiman Hussein and Garira Talal Suleiman. (2015). Significance of applying strategic cost management and competition strategies to achieve the competitive advantage of Jordanian public industrial firms. Journal of Administrative Science Studies, Jordan: The Jordanian University, Vol. 42, issue, No. 1, p. 181. Bin Saeed Amin and Ahmad Gadar, (2013). The role of cost management from a strategic perspective to enhance the competitive position. Journal of Economic and Financial Studies, Algeria: Alwadi University, vol. I, No. 6, p. 8.

4. Gumoa Abu Anga Mahmoud Abdallah, (2015) Strategic analysis methods and their role in achieving costs in industrial firms, unpublished $\mathrm{PhD}$ in accounting, Khartoum: Sudan University of Science and Technology.

5. Afaf Zahrawi. (2009). modeling and evaluating modern production methods performance in Algerian industrial firms using Terry networks. Unpublished Master Degree in Economic Sciences, Algeria: Mentouri University, p. 73.

6. Abdul Aziz, Ahmed Saeed. (2013). An analytical study to measure the of integration of flexible accounting system and strategic cost analysis management (an applied study on new and renewable energy projects), $\mathrm{PhD}$ in accounting, unpublished, Egypt: Suez Canal University, p. 135.

7. Eid, Amani Ramadan Ibrahim. (2006). A perspective of strategic cost analysis with a view to rationalizing administrative decisions in industrial firms in modern environment, $\mathrm{PhD}$ in accounting, unpublished, Egypt: Tanta University, pp. 74-82.

8. Fouda, Shawqi Elsaid (2007). A Proposed Model for integration between target cost and strategic cost analysis to allocate activity-based costing through the concept of value chain, The Journal of the faculty of commerce, for scientific research, Alexandria: Alexandria University, Vol. 44, No. 2, p. 178.

9. ffAl Qanna, Ahmed Saad Abdul Aziz. (2013). An analytical study to measure the integration of flexible accounting system and strategic cost analysis management, An applied study on new and renewable energy projects, PhD in accounting, unpublished, Egypt: Suez Canal University, p. 48.

10. Majda Abu Zane. The effect of strategic orientation on code of ethics, an exploratory study, Secretariat General of the Council of Notables, Journal of administration and accounting and insurance, issue No 78, fifth year, 2011.

11. Mohamed, Mohamed Al-fayyoumi. (2012). Strategic Accounting (financial performance evaluation of firms, responsibility accounting, quality costs, Finance prices, Theory of Constraints, strategies and methods of pricing). Alexandria: University Education publishing, printing and distribution house, p. 216.

12. Nouri, Haidar Shaker, and Gomaa, Mahmoud Hassan. (2014). Strategic cost management techniques. Research Journal, Iraq: Diyala University, No. 63, p. 289. 